DOI 10.37882/2223-2982.2021.01-2.03

\title{
ЭЛЕКТРОННЫЙ ИЛЛЮСТРИРОВАННЫЙ МНОГОЯЗЫЧНЫЙ СЛОВАРЬ ВОЕННЫХ ТЕРМИНОВ КАК СРЕДСТВО МЕЖДУНАРОДНОГО ВОЕННОГО СОТРУДНИЧЕСТВА
}

\section{ELECTRONIC ILLUSTRATED MULTILINGUAL DICTIONARY OF MILITARY TERMS AS A TOOL FOR INTERNATIONAL MILITARY COOPERATION}

I. Balkanov

Summary: This article substantiates theoretical foundations of a modern multilingual dictionary of special (military) terms, which development is only possible in the process of integration and cooperation between higher military educational institutions, defense businesses, military command authorities, theoretical lexicographers, programmers and military interpreters. The study provides theoretical and practical recommendations for the structure of the electronic illustrated multilingual dictionary of special (military) terms, proposes and describes the stages of its development.

Keywords: translation dictionary, military vocabulary, military terminology, bilingual lexicography, minimal dictionary, microstructure of electronic illustrated translation dictionary.

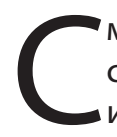
момента обретения независимости бывшими республиками Советского союза вопросы военного и военно-технического сотрудничества независимых государств не только не сходили с повестки дня, но по мере расширения международных контактов, в том числе в военной сфере, становились все более актуальными.

Совместные действия вооруженных сил различных государств, будь то международные учения, миротворческие операции, олимпиады или армейские игры, требуют всесторонней и тщательной подготовки, немаловажным элементом которой является работа с документами, которая осуществляется на всех языках странучастниц того или иного мероприятия, а также зачастую на английском языке - языке международного общения.

Отрабатывая различные вопросы в ходе планирования и проведения совместных мероприятий, военные специалисты говорят на одном языке - языке военных терминов, не допускающем вольного толкования и неточного перевода понятий, ведь от этого зависит не только успех операции, но и жизни солдат и офицеров. Под военным термином мы понимаем «устойчивое однословное или несколькословное наименование, за-
Балканов Илья Владимирович

К.филол.н., дочент, Военный университет Министерства обороны Российской Федерации, Москва

i-balkanov@mail.ru

Аннотация: Данная статья закладывает теоретические основы современного многоязычного словаря специальных (военных) терминов, создание которого возможно только при условии тесного взаимодействия преподавателей высших военно-учебных заведений, представителей оборонно-промышленного комплекса и органов военного управления, ученых-лексикографов, программистов и военных переводчиков. В результате исследования выработаны теоретические и практические рекомендации по организации структуры электронного иллюстрированного многоязычного словаря специальных (военных) терминов, описаны этапы его создания и порядок работы на каждом из этапов.

Ключевые слова: переводной словарь, военная лексика, военная терминология, двуязычная лексикография, словарь-минимум, микроструктура электронного иллюстрированного переводного словаря.

крепленное за соответствующим понятием в системе понятий определенной области военной науки и военной техники и ограниченное специальной сферой употребления в значении, строго регламентированном его дефиницией» [1, с. 16].

Говоря о военной терминологии, нельзя обойти стороной оборонно-промышленный комплекс. Огромный объем документации - от договоров и контрактов до руководств по эксплуатации - переводится на родной язык страны-покупателя и/или на английский язык как язык международного сотрудничества. При этом общие и специальные (отраслевые) словари и терминологические глоссарии, используемые в процессе перевода и обучения иностранных военнослужащих, и уровень языковой и специальной (военной и военно-технической) грамотности специалистов отличаются от компании к компании и от страны к стране, что негативно сказывается на качестве перевода и развитии военного и военно-технического сотрудничества в целом. Кроме того, «состав современной военной и военно-технической терминологии не является постоянным. Он непрерывно изменяется за счет выпадения ряда слов, изменения значений, непрерывного пополнения новыми терминами, например, в связи с реорганизацией видов вооруженных сил, 
появлением и разработкой новых образцов вооружения и боевой техники, разработкой новых методов ведения войны и т.д.» [2, с. 15].

Учитывая особую роль военного переводчика в процессе международной военной и военно-технической коммуникации и специфику его работы, мы приходим к понимаю того, что только электронный иллюстрированный военный переводной словарь обеспечит высокое качество подготовки данных специалистов, предоставит им электронный ресурс, дающий возможность оперативно узнавать обо всех изменениях, происходящих в военной сфере, и осуществлять быстрый и точный письменный и последовательный перевод.

Следует отметить, что все военные образовательные организации в процессе подготовки военных специалистов используют иллюстративный материал (плакаты, схемы, таблицы), дающий будущим офицерам наглядное представление о том, как выглядит и как устроен тот или иной механизм, система вооружения. Рабочие программы дисциплин, используемые в процесс подготовки будущих сержантов, старшин, прапорщиков и офицеров в разных военных учебных заведениях, имеют много общего.

Bсе вышесказанное позволяет нам говорить о целесообразности объединения усилий преподавателей военных учебных заведений с теоретическими и практическими наработками военных лексикографов, составителей общих и специальных военных словарей, и практикующих военных переводчиков. Подобная практика успешно реализуется на Западе. Так, еще в первые годы Второй мировой войны совместный труд американских военных специалистов и переводчиков привел к созданию более 200 словарей и глоссариев по военной терминологии, а современный Военный переводной словарь Министерства обороны США с 2016 г. претерпел уже более 15 переизданий. «Неоспоримым преимуществом американских двуязычных военных словарей является тот факт, что они были созданы коллективом авторов... Это позволило в кратчайшие сроки заложить теоретические и практические основы мега-, микро- и макроструктуры военного переводного словаря, разработать и регулярно переиздавать военные словари для основных европейских и азиатских языков» [3, с. 134].

К сожалению, после распада Советского союза аналогичные проекты в наших странах (например проект «Воениздата» по составлению отраслевых военных словарей) практически прекратили свое существование. В настоящее время существует крайне малое количество иноязычных военных словарей, лексика в них устарела и не отвечает современным реалиям военной сферы. Все они являются печатными изданиями, что на современном этапе развития вооруженных сил в контексте иду- щих вокруг нас процессов глобализации, цифровизации и погружения в единую информационно-коммуникационную среду является признаком отсталости.

Работу по созданию электронного военного многоязычного словаря, который, как и любой другой переводной словарь, представляет собой «определенным образом расположенную совокупность зафиксированных правил замены элементов лексики одного языка эквивалентными им по смыслу элементами другого языка» [4, с. 6], целесообразно разбить на несколько этапов.

На первом этапе мы предлагаем разработать электронный русско-английский (англо-русский) учебный иллюстрированный словарь-минимум, ориентированный на программу подготовки военных переводчиков. Электронный формат позволит постоянно и оперативно дополнять словарь новыми разделами, постепенно его углублять и расширять, оперативно реагировать на последние изменения в военной теории и практике.

Электронная версия учебного иллюстрированного словаря-минимума будет интегрирована в электронные учебные пособия и дидактические материалы по военному переводу, дисциплинам военной подготовки (тактика, вооружение и военная техника, и т.д.), в процесс обучения иностранному языку в видовых военных учебных заведениях.

Семантический, или тематический, подход к организации макроструктуры словаря, в рамках которого «словарные статьи создаются путем объединения общих по значению лексических единиц на основании той или иной системы отношений между ними» [5, с. 205], равно как и вовлечение в процесс составления словарей офицеров-преподавателей специальных военных дисциплин и практикующих военных переводчиков исключит неправильное толкование и/или перевод терминологических единиц.

Семантический подход успешно «используется в отечественной лексикографии при создании общих и специальных переводных словарей» [3, с. 62], в том числе военных, как например Иллюстрированный военно-технический словарь Л.Л. Нелюбина, который, по мнению его составителя, «относится к типу так называемых картинных словарей, в которых термины группируются по предметно-тематическому принципу» [6, с. 3].

Работа на данном этапе начинается с составления списка военных терминов профильными военными образовательными организациями в целях последующего перевода данных терминов и включения их в электронную оболочку словаря (порядка тысячи терминологических единиц на каждую область военного дела). Военные образовательные учреждения формируют список во- 
енных (военно-технических, военно-специальных) терминов на русском языке с учетом своей специфики по определенным тематическим разделам (организационно-штатная структура, боевое применение, повседневная деятельность войск, боевая подготовка, вооружение и военная техника, подаваемые команды, и др.). Каждый термин сопровождается кратким определением, указанием на сферу применения и частотность употребления, а также иллюстративным материалом (рисунком, фотографией, схемой, графиком, видеофайлом). При этом значения отобранных терминов, согласно И.Р. Гальперину, «располагаются по употребительности с учетом их логических связей» [7, Т. 1, с. 29].

Итоговый терминологический список подготавливается в текстовом редакторе в единой кодировке, где для описания одного термина используется один абзац. Это упрощает процесс переноса терминологической базы в электронную оболочку и превращает словарь в «систему лексикографических данных (словарных статей), упорядоченную с помощью специальной программы, которая позволяет выполнить поиск переводного эквивалента лексической единицы входного языка» [3, с. 79].

Терминологический список даст лексикографам и программистам возможность работать с изначально упорядоченным лексическим материалом входного языка и привязать к каждой конкретной словарной статье файлы, содержащие толкование заглавного слова, перевод, иллюстративную и экстралингвистическую информацию, и таким образом сформировать микроструктуру электронного словаря военных терминов. Сведения о частотности употребления и терминологической области позволяют упорядочить леммы по семантическому принципу, оформят макроструктуру словаря и сделают его семантическим. Включение в словарь примеров употребления заглавных слов, которые «показывают, как заглавные слова ведут себя в сочетаниях с другими лексическими единицами, раскрывают морфологические, синтаксические и стилистические особенности лексических единиц и наглядно демонстрируют возможности лексической сочетаемости» [8, с. 104], и фразеологии, которая «входит наряду с лексикой в словарный состав языка как его весьма существенная часть» [9, с. 6], повысит практическую значимость словаря для военных переводчиков и сделает его менее зависимым от других электронных ресурсов (корпусов текстов, программ машинного перевода, поисковых систем в интернете), доступ к которым в военных организациях зачастую ограничен.

На втором этапе мы предлагаем увеличить количество иностранных языков за счет добавления терминов на других иностранных языках, (арабский, немецкий, персидский, турецкий и т.д.), в том числе на языках Coдружества независимых государств и языках Организации Договора о коллективной безопасности.

На третьем этапе возможно увеличение количества терминов и примеров в целях трансформации словаряминимума в полный многоязычный иллюстрированный словарь-энциклопедию, расширяющий фоновое знание, или «обоюдное знание реалий говорящим и слушающим» [10, с. 498], о военное сфере. На данном этапе к работе над составлением словаря целесообразно привлечь представителей оборонно-промышленного комплекса, а сам словарь (или его экспортный вариант) впоследствии поставлять вместе с оборонной продукцией иностранному заказчику, что значительно упростит процесс освоения отечественной военной техники, сократит затраты времени на подготовку специалистов, отвечающих за ее ремонт и эксплуатацию, и позволит сделать проект коммерчески окупаемым.

Все вышесказанное позволяет нам выступить с предложением унифицировать военную иноязычную терминологию в форме электронного многоязычного словаря военных терминов - инновационное решение проблем военной терминологии, возникающих в процессе подготовки специалистов, проведении совместных мероприятий и поставках вооружения на экспорт. К работе над словарем считаем необходимым привлечь специалистов в области военного и военно-технического сотрудничества, военных лингвистов (лексикографов, преподавателей иностранного языка и перевода, практикующих военных переводчиков), программистов и представителей отечественного оборонно-промышленного комплекса.

\section{ЛИТЕРАТУРА}

1. Шевчук, В.Н. Военно-терминологическая система в статике и динамике: автореф. дис. ... д-ра филол. наук: 10. 02.19 / В. Н. Шевчук. - М., 1985. - 43 с.

2. Нелюбин, Л.Л. Учебник военного перевода. Английский язык / Л. Л. Нелюбин. - М.: Воениздат, 1981. - 379 с.

3. Балканов, И.В. Теоретические аспекты двуязычной лексикографии (на материале военных переводных словарей): дис. .... канд. филол. наук: 10.02.20 / И.В. Балканов. - М., 2017. - 194 с.

4. Берков, В.П. Вопросы двуязычной лексикографии (словник) / В.П. Берков. - Л.: Изд-во Ленингр. ун-та, 1973. - 190 с.

5. Nielsen, S. Dictionary Structures / S. Nielsen // Bergenholtz and Tarp, Manual on Specialized Lexicography. - Amsterdam: John Benjamins Publishing Company, 1995. - P. $200-211$.

6. Нелюбин, Л.Л. Иллюстрированный военно-технический словарь / Л. Л. Нелюбин. - М.: Воениздат, 1968. - 486 с.

7. Большой англо-русский словарь: ок. 150000 слов / под общ. руковод. д-ра филол. наук, проф. И.Р. Гальперина. - М.: Совет. энцикл., 1972. - 2 т. 
8. Yong, H. Bilingual Lexicography from a Communicative Perspective / H. Yong, J. Peng. - Amsterdam: John Benjamins Publishing Company, 2007. - 229 p.

9. Большой немецко-русский словарь / Е.И. Лепинг [и др.]; под. общ. рук. 0.И. Москальской. - 11-е изд., стереотип. - М.: Рус. яз. Медиа, 2008. - 760 с.

10. Ахманова, 0.С. Словарь лингвистических терминов / О.С. Ахманова. - М.: Совет. энцикл., 1966. - 608 с.

○ Балканов Илья Владимирович (i-balkanov@mail.ru).

Журнал «Современная наука: актуальные проблемы теории и практики»

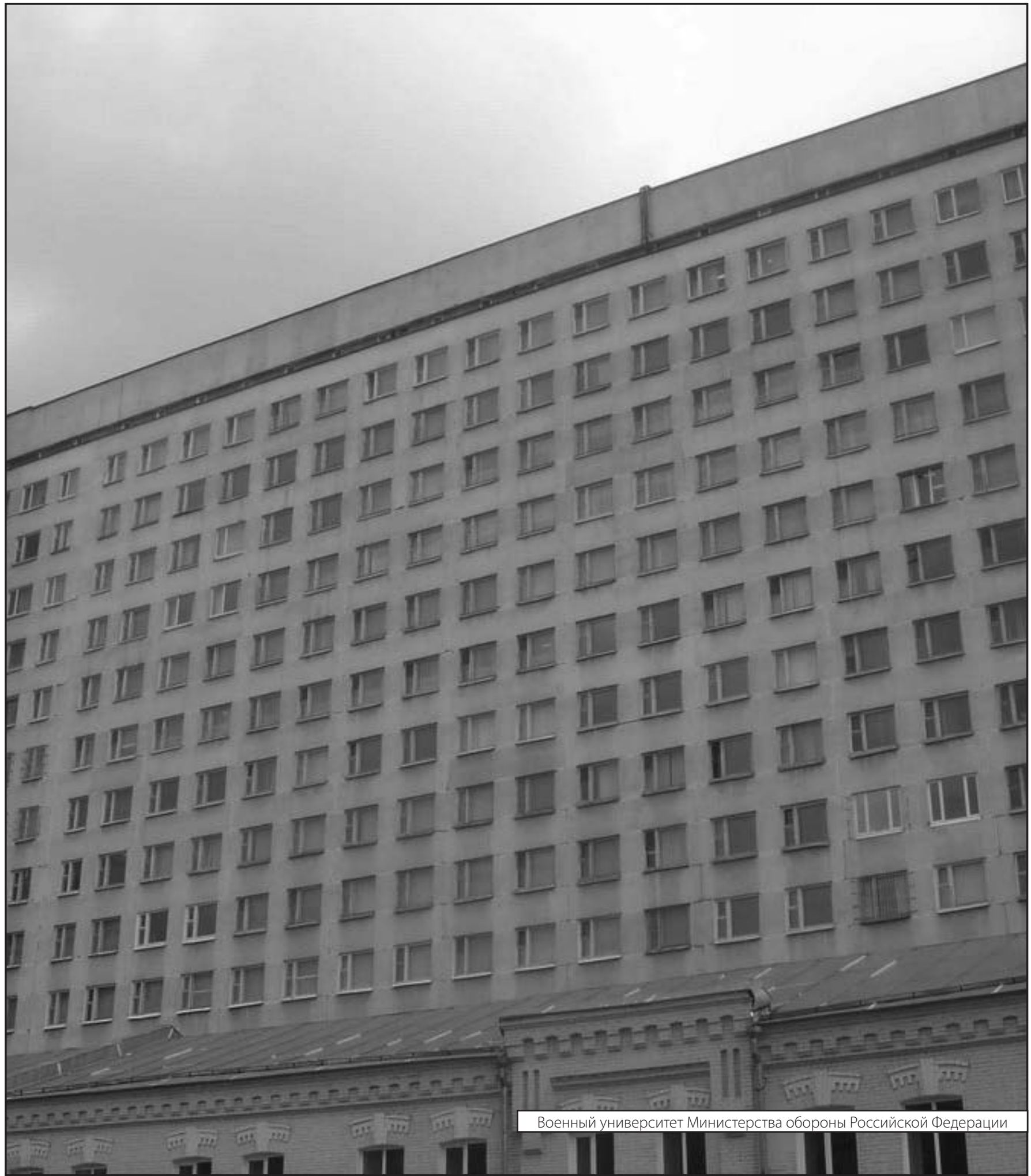

